\title{
Public Perception Pricing into Vehicle Biofuel Policy in Indonesia
}

\author{
Tri Tjahjono ${ }^{1 *}$, Andyka Kusuma ${ }^{1}$, Mohammad Adhitya ${ }^{2}$, Robby Yudo Purnomo ${ }^{1}$, \\ Talitha Azzahra ${ }^{1}$, A. Joko Purwanto ${ }^{3}$, Gari Mauramdha ${ }^{1}$ \\ ${ }^{1}$ Department of Civil and Environmental Engineering, Faculty of Engineering, Universitas Indonesia, \\ Kampus UI Depok, Depok 16424, Indonesia \\ ${ }^{2}$ Department of Mechanical Engineering, Faculty of Engineering, Universitas Indonesia, Kampus UI Depok, \\ Depok 16424, Indonesia \\ ${ }^{3}$ Economic Research Institute for ASEAN and East Asia (ERIA), Central Jakarta 10270, Indonesia
}

\begin{abstract}
The Indonesian government established that Indonesia would implement EURO IV standard emissions by the end of 2021. Furthermore, to enhance the corresponding policy, the Indonesian government also eliminated policy incentives for fossil fuels, such as the fuel price subsidy. As an alternative, the government now supports biofuel as a new fuel technology to improve environmental conditions and increase palm production in Indonesia. The aim of this paper is to determine public perception toward the pricing policy at the time biofuel is introduced. We apply a discrete choice model through a stated preference survey. We found that the majority of people would shift to biofuel and particularly to green diesel, despite its higher price than current fuels, due to its similar molecular structure to petroleum diesel and its even better diesel properties. However, this condition only applies if no other alternative exists and if implementing EURO IV standard emissions becomes mandatory. Moreover, the implementation of biofuel and the EURO IV policy will also affect vehicle demand and purchases. Therefore, vehicle manufacturers need to be prepared for the increasing demand for particular types of vehicles.
\end{abstract}

Keywords: Biofuel; Demand; Discrete choice model; Stated preference

\section{Introduction}

Indonesia has introduced a biofuel policy, and an increase of $23 \%$ usage is expected by the end of 2024 (Ministry of National Development Planning, 2020). This policy forms part of the government's strategy to shift to greener energy sources and its commitment to sustainable development goals. This policy will also cope with the country's fuel problems, considering the substantial amount of crude oil production. Despite the increased demand for fossil fuels in Indonesia, the government insists on implementing the EURO IV standard emissions. Since May 2016, Indonesia has decided not to extend its membership in the Organization of the Petroleum Exporting Countries (OPEC) (Jensen and Asmarini, 2016). It has now become a net importer of oil (due to the decline in production and a rapid increase in domestic consumption) and can no longer meet its production quota.

OPEC itself is an intergovernmental organization of 13 countries that aims to "coordinate and unify petroleum policies of its member countries and ensure the stabilization of oil markets, to secure an efficient, economical, and regular supply of

${ }^{*}$ Corresponding author's email: tri.tjahjono@ui.ac.id, Tel.: +62-81311461022; Fax.: +62-21-7270028 doi: 10.14716/ijtech.v12i6.5219 
petroleum to consumers, a steady income to producers, and a fair return on capital for those investing in the petroleum industry" (Organization of the Petroleum Exporting Countries, 2021). Furthermore, the reserves of crude oil in Indonesia are relatively low, especially compared to Venezuela (one of the biggest oil exporters in the world). Despite all its problems, Indonesia has considerable numerous potential for coping with its fuel problem. One example is the utilization of palm oil as an alternative fuel, as Indonesia is well known as one of the world's biggest palm oil exporters. Therefore, Indonesia intends to implement a biofuel policy starting in 2030. As an alternative fuel option, palm biofuel offers several advantages, such as cheaper production costs, cleaner production methods, and reduced environmental issues (Kaniapan et al., 2021).

Along with implementing this biofuel policy, the Indonesian government has also insisted on implementing the EURO IV emission standard, as Indonesia still currently implements the EURO II emission standard. The shift from EURO II to EURO IV is a breakthrough move, considering the significant reduction in the emission limits. For example, the limits for Petrol NOx in EURO II versus EURO IV are $0.5 \mathrm{~g} / \mathrm{km}$ and $0.08 \mathrm{~g} / \mathrm{km}$, respectively, equivalent to an $84 \%$ reduction. However, the upgraded emission standard is beneficial, particularly for supporting the Paris Agreement to restrain the increase in global temperature to $2^{\circ} \mathrm{C}$ (preferably $1.5^{\circ} \mathrm{C}$ ) compared to the preindustrial level (United Nations, 2016).

The aim of the present research is to analyze the public perception of the new pricing scheme regarding biofuels in Indonesia. Moreover, the research considers some issues, such as subsidized fuel removal and the EURO IV emission standard implementation. A further aim of the research is to attempt to forecast the potential growth of vehicle purchases based on people's willingness to pay. The paper consists of several sections: introduction, literature review, methodology, results, analysis, and conclusion.

\subsection{Literature Review}

\subsubsection{Biodiesel technology}

The transport sector is one of the slowest sectors in terms of decarbonization and varies little based on the energy sources (International Energy Agency, 2017; Fadiran et al., 2021). Fossil fuels are not environmentally friendly, as they produce greenhouse gas (GHG) emissions and deplete an exhaustible resource. Consequently, recent developments have introduced biofuel technology, which is based on renewable organic materials. The second generation of biodiesel, called green diesel, is given a code "D" instead of "B" (e.g., D100) in Indonesia.

Green diesel, also known as biohydrocarbon diesel, is a high-speed diesel engine fuel derived from vegetable materials through certain process technologies that create a hydrocarbon oil with no oxygen content. Hydrotreatment of triglycerides with hydrogen produces green diesel from vegetable oils (Neonufa et al., 2017). The green form is far superior to biodiesel as its molecular structure is similar to petroleum diesel but it has even better diesel properties, including a higher cetane number, lower sulfur content, better oxidation stability, and clearer color than biodiesel. The molecular structure similarity of D100 biohydrocarbon to that of petroleum diesel allows the direct use (drop-in) of green diesel as a substitute for fossil fuels without adjustment of the vehicle engine.

Experiments with green diesel have shown positive results, including no excessive engine noise, as well as increased engine power and cleaner exhaust emissions even at high RPM. This better performance will result in more efficient fuel consumption, as well as a prolonged engine lifetime (Othman et al., 2017). However, several piece of studies have shown a need for capital in research and development to extract and define the optimum composition of biofuels, as defining an optimum market price for B.100 types is difficult 
without any fiscal incentive. In fact, providing a long-term incentive creates a burden on biofuel industry sustainability. Kutas et al. (2007) applied cost-benefit analysis to capture a successful biofuel blending strategy, as blending fossil and green fuels can be a solution that can provide an optimum market price in countries like Germany (Ninni, 2010), Brazil (Cavalcanti et al., 2012), the USA (Grafton et al., 2012), and China and India (Hassan and Kalam, 2013).

Biodiesel, as a biofuel for diesel engine applications, consists of fatty-acid-methylesters (FAMEs) made from vegetable oil or animal fat through an esterification/transesterification process. The transesterification process removes alcohol from the ester using alcohol or methanol as a catalyst (Demirbas, 2009). Biodiesel in the form of FAMEs can be mixed with petroleum diesel in certain volume percentages known as B15, B20, or B30. B30, for example, contains as much as 30\% FAME biodiesel in the total volume of B30 fuel, with the remaining $70 \%$ ordinary petroleum diesel. The minimum mandatory steps for mixing biodiesel with petroleum diesel, based on the Indonesian Ministry of Energy and Mineral Resources (ESDM) Regulation Number 12 of 2015, are shown in Table 1.

Table 1 The minimum mandatory steps for biodiesel and petroleum mixing

\begin{tabular}{lcccc}
\hline \multicolumn{1}{c}{ Sector } & Apr 2015 & Jan 2016 & Jan 2020 & Jan 2025 \\
\hline Public Service Obligation & $15 \%$ & $20 \%$ & $30 \%$ & $30 \%$ \\
Non-PSO Transport & $15 \%$ & $20 \%$ & $30 \%$ & $30 \%$ \\
Power Plant & $25 \%$ & $30 \%$ & $30 \%$ & $30 \%$ \\
Industry and Commercial & $15 \%$ & $20 \%$ & $30 \%$ & $30 \%$ \\
\hline
\end{tabular}

\subsubsection{Road user perception in fuel price}

Indonesia plans to apply biofuel vehicle technology in 2030. However, an issue in pricing arises, as the price may differ from the conventional fuel price. Several types of fuel in Indonesia are subsidized, such as premium and solar, as a way to promote and increase biofuel attractiveness. The Indonesian government released Presidential Regulation 191 for the year 2014 that regulates subsidized biofuel use.

A biofuel policy will not succeed if the road user is reluctant to use the biofuel based on the market price. However, both the fuel producers and the vehicle producers can cope with the technology, and they are ready for an investment in massive production. A need exists to assess the road users' views of an acceptable price through a willingness-to-pay methodology. A continuous public campaign in green energy can also increase society's awareness and the technology surrounding the choice of environmentally friendly fuels (Karytsas and Theodoropoulou, 2014). A recent study found a positive impact of functional value on people's willingness to pay for biofuels. This effect suggests that people's willingness is significantly influenced by biofuel price and quality. The research showed that most of the respondents were willing to pay $10 \%$ more for biofuels, and they considered a $10 \%$ higher price to be acceptable (Zailani et al., 2019). A similar finding was found in an ethanol price willingness-to-pay study, where the road users tended to pay a higher price for E85 rather than E10 fuel due to the environmental benefit of E85 (Jensen et al., 2010; Susaeta et al., 2010). Other studies show a request for discounted prices (Li and McCluskey, 2017).

\section{Methods}

\subsection{Data Collection}

Prior to data collection, two assumptions must be explained to the survey respondents. The first assumption is that fuel subsidies will be removed in the next couple of years. This 
assumption is based on the government plan to remove subsidized fuel as a complementary policy toward biofuel penetration. The second assumption involves the implementation of the EURO IV emission standard, as people who are willing to shift into EURO IV are assumed to be those who have substantial environmental awareness. Table 2 shows a description of the independent variables for the determination of people's willingness to pay. We hypothesize that socioeconomic variables, such as occupation and income, have a significant influence on willingness to pay (Karytsas and Theodoropoulou, 2014; Tsay, 2009). Other variables may also be used in the analysis, such as travel frequency, travel distance, or respondent's age. However, based on early analysis, those variables seem to have no significant impact on people's preferences.

Table 2 Explanatory variables description

\begin{tabular}{|c|c|c|c|c|c|}
\hline \multirow{2}{*}{$\frac{\text { No. }}{\mathrm{X}_{1}}$} & \multirow{2}{*}{$\begin{array}{l}\text { Description } \\
\text { Fuel type }\end{array}$} & \multicolumn{4}{|c|}{ Choice Set } \\
\hline & & Diesel & $\begin{array}{l}\text { 1: Solar/Biosolar } \\
\text { 2: Dexlite } \\
\text { 3: Pertamina Dex }\end{array}$ & $\begin{array}{l}\text { Non- } \\
\text { diesel }\end{array}$ & $\begin{array}{l}\text { 1: Pertalite } \\
\text { 2: Pertamax } \\
\text { 3: Pertamax Tubo }\end{array}$ \\
\hline $\mathrm{X}_{2}$ & Location & \multicolumn{4}{|c|}{$\begin{array}{l}\text { 1: Jakarta; } \\
\text { 2: Bandung; } \\
\text { 3: Bogor }\end{array}$} \\
\hline $\mathrm{X}_{3}$ & Occupation & \multicolumn{2}{|c|}{$\begin{array}{l}\text { 1: Government/Military/Police } \\
\text { 2: Private } \\
\text { 3: Entrepreneur } \\
\text { 4: Student }\end{array}$} & \multicolumn{2}{|c|}{$\begin{array}{l}\text { 5: Freelance/Jobseeker } \\
\text { 6: Unemployed } \\
\text { 7: Others }\end{array}$} \\
\hline $\mathrm{X}_{4}$ & Income & \multicolumn{2}{|c|}{$\begin{array}{l}\text { 1: } 0-5 \mathrm{mio} / \mathrm{month} \\
2: 6-20 \mathrm{mio} / \mathrm{month}\end{array}$} & \multicolumn{2}{|c|}{$\begin{array}{l}3: 21-50 \mathrm{mio} / \mathrm{month} \\
4:>51 \mathrm{mio} / \mathrm{month}\end{array}$} \\
\hline $\mathrm{X}_{5}$ & $\begin{array}{l}\text { Environment } \\
\text { awareness }\end{array}$ & \multicolumn{4}{|c|}{$\begin{array}{l}0: \text { No } \\
1: \text { Yes }\end{array}$} \\
\hline $\mathrm{X}_{6}$ & Fuel price & \multicolumn{4}{|c|}{ Current respondents' fuel price } \\
\hline
\end{tabular}

In this paper, the shared attributes are location (Jakarta, Bandung, or Bogor) and vehicle type (Diesel or Non-diesel). We used stratified random sampling, which involves the division of a population into smaller sub-groups known as strata (Arnab, 2017). Although the sampling is random, the data collection consists only of interviews of the owner of the vehicle to obtain a better perception regarding the willingness to pay, since the vehicle owner would be the one who pays all the vehicle expenses.

\subsubsection{Study location}

The survey was conducted at a gas station to ensure that the respondent was a vehicle user, although the respondent still required validation through the questionnaire. The reason for choosing Jakarta, Bandung, and Bogor as the survey locations was the differences in people's characteristics. Jakarta, the capital city of Indonesia, has the highest economic growth and represents an urban lifestyle. Bandung is the capital city of West Java Province. Although its population is not as dense as that of Jakarta, Bandung could also represent the urban people's behavior. Bogor is one of the largest cities in West Java, and it represents the boundaries between urban and suburban areas. Other cities had the potential to be survey locations; however, due to the pandemic situation, long distance travel was not possible.

\subsubsection{Stated preference survey}

The questionnaire consists of several hypothetical questions concerning the respondent. Therefore, the method could be classified as a stated preference survey (attitudinal). Stated preference methods attempt to learn people's willingness to pay by directly asking them the value of certain alternatives or services through carefully 
formulated surveys. The surveys are designed to create a hypothetical market in which respondents make decisions on relevant alternatives. When responding to a survey, the respondents do not face the real conditions in the market when they answer a specific question; therefore, the answer given in a hypothetical situation may not reflect their true willingness to pay, particularly in the current situation where the pandemic has generally reduced people's purchasing power. Furthermore, the answers a respondent gives depend on how the questions are framed in the questionnaire (Diamond and Hausman, 1994).

The questionnaire opens with the validation process, which consists of two (two) questions regarding: (1) vehicle ownership; and (2) vehicle type. To be an eligible respondent, the answer to the two questions should be: (1) Yes; and (2) Car. After the validation process, the respondent is then presented with: (1) socioeconomic questions, such as age, gender, occupation, and income; and (2) travel characteristic questions, such as travel frequency, travel distance, and weekly expenditure on transportation. The next phase of the questionnaire is the stated preferences question. The respondent is given several scenarios and must choose one of the scenarios. Each scenario involves a new fuel price as a percentage, due to the current fuel price fluctuation. The question starts with the highest possible price (30\% higher than the current price). If the respondent is not willing to pay that particular price, the question continues until the lowest possible price $(10 \%$ lower than the current price). The last step of the questionnaire is to probe the willingness to use the EURO IV emission standards.

\subsection{Discrete Choice Model}

The discrete choice model is the cornerstone model developed to predict travel behaviors, specifically the choices of modes of transportation, time of day, destinations, and even routes. Discrete choice models are developed based on the theory of random utility maximization (RUM). RUM assumes that, when choosing from a set of discrete alternatives (e.g., mode choices and destination choices), the decision maker is aware of all feasible alternatives and their associated attributes and is willing to make trade-offs across attributes. Given these conditions, the decision maker then chooses the choice that will maximize his or her satisfaction (Ben-Akiva and Lerman, 1985). This study extends the application of the willingness-to-pay approach to capturing road user preferences regarding biofuel technology in Indonesia. In the discrete choice model, the alternatives could consist of two options (binary) or more than two options (Train, 2009; Ortuzar and Willumsen, 2011). The road user faces a discrete situation: either staying or shifting to biofuel technology if the driver preference does not differentiate between the two fuel types. Moreover, the driver considers their out-of-pocket money for shifting their vehicle technology in this case. This situation involves analyzing the discrete choice model, which is a common tool for the analysis of people's perceptions regarding several available alternatives. In this research, the discrete choice model is used to determine why people choose biofuel alternatives over the current fuel. Therefore, the choice set is divided into a willingness or reluctance to use biofuel.

The analysis and comparison of the two alternatives (current fuel and biofuel) requires the development of a utility function to understand the initial knowledge of the significant and crucial variables that affect people's decisions (Honore and Kyriazidou, 2000; Train, 2009; Ortuzar and Willumsen, 2011). As only two alternatives are available, the binomial logit model would be the appropriate approach. The general utility function of the alternatives would be the following:

$$
U_{i}=\beta_{1} X_{1 i}+\beta_{2} X_{2 i}+\beta_{3} X_{3 i}+\beta_{4} X_{4 i}+\ldots+\beta_{n} X_{n i}
$$




$$
\begin{gathered}
U_{j}=\beta_{1} X_{l j}+\beta_{2} X_{2 j}+\beta_{3} X_{3 j}+\beta_{4} X_{4 j}+\ldots+\beta_{n} X_{n j} \\
U_{i-j}=\beta_{1}\left(X_{l i}-X_{l j}\right)+\beta_{2}\left(X_{2 i}-X_{2 j}\right)+\beta_{3}\left(X_{3 i}-X_{3 j}\right)+\ldots+\beta_{n}\left(X_{n i}-X_{n j}\right)
\end{gathered}
$$

where $U_{i}$ and $U_{j}$ stand for the utility function for alternatives $i$ and $j$, respectively, while $\beta$ is the variable parameter of the alternatives and $X$ is the variable of the alternatives. The variables consist of Alternative Specific Constant (ASC), socioeconomic variables, and the trade-off between alternatives. The probability of particular people choosing any alternatives depends on the utility value and can be determined by the following formula:

$$
P(i-j)=\frac{1}{\left[1+e^{-(U i-U j)}\right]}=\frac{e^{U i}}{e^{U i}+e^{U j}}
$$

The choice in this paper is binary, whereby each individual has the choice of precisely two alternatives. This paper observes the choice of each individual to either stay with or shift from the current fuel to biofuel with respect to the perception of environmental impact improvement and better vehicle performance. Therefore, this situation is considered a binary choice model. The choice model assumes that the random error term is independent and identically distributed (IID).

\section{Results and Discussion}

\subsection{Respondent's Characteristics}

The data collection divided the respondents based on their vehicle engine type and the survey location, as these factors could affect the respondents' willingness to pay. Significantly more males than females responded to the survey, and this was connected to the focus of this survey, as the data collection concentrated on diesel fuel users. The respondent's car type was also correlated with this gender difference, as most respondents used large vehicles, such as SUVs or MPVs, which are more likely to be driven by males. The largest proportion of the respondents had occupations as workers in state-owned companies, the next largest proportion consisted of workers in the private sector, and the final proportion were entrepreneurs/merchants in Bandung and Jakarta. In general, the same assumptions can be made depending on the type of vehicle involved in the company.

Figure 1 shows the respondents' characteristics for occupation and income. From the occupation point of view, most people in each region work at state-owned companies or in the private sector, followed by entrepreneurship and students. Most respondents received around IDR 6-20 million per month as income, followed by IDR 0-5 million per month. These results are consistent with the minimum wage levels in Jakarta, Bandung, and Bogor, which are IDR 4.4 million, IDR 3.6 million, and IDR 4.1 million, respectively.

The respondents' fuel spending results correlate with how often or how far they travel per week; the results vary widely. Most people surveyed expend around IDR 200-400 thousand/week. The greatest proportion of people spending more than IDR 500 thousand/week is in Jakarta (20\%), followed by Bogor (9\%), and then Bandung (8\%). The greatest proportion of respondents in Bogor spend IDR 200-300 thousand/week (35\% of the respondents), and the greatest proportion of respondents in Bandung spend IDR 300400 thousand per week (28\% of the respondents).

As stated in the previous section, the willingness to shift into the EURO IV emission standard is transformed into an explanatory variable of environmental awareness. Based on the data collection, two of the survey locations, Jakarta, and Bandung, show a similar pattern of the people's willingness to shift to the new fuel. Approximately $86 \%$ of the total respondents in both cities are willing to shift. 


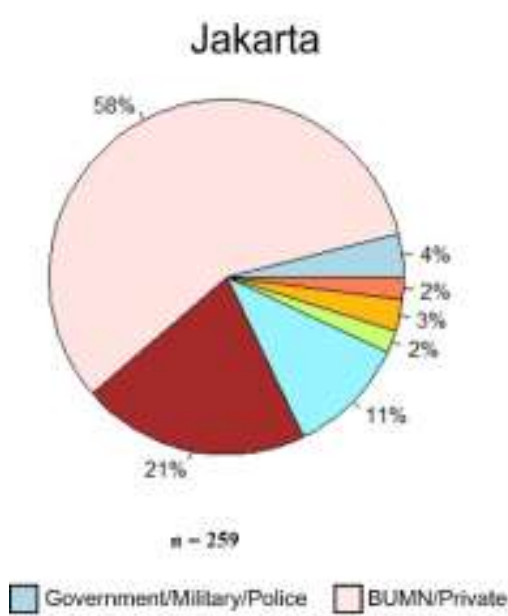

GovernmentMillaryiPolice

Jakarta

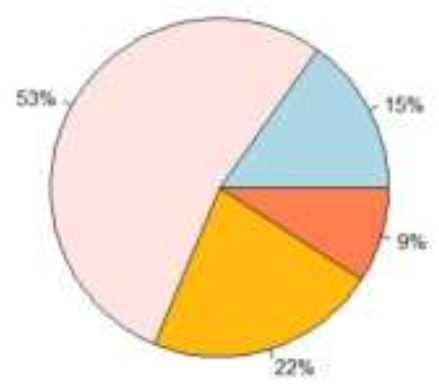

$n-259$

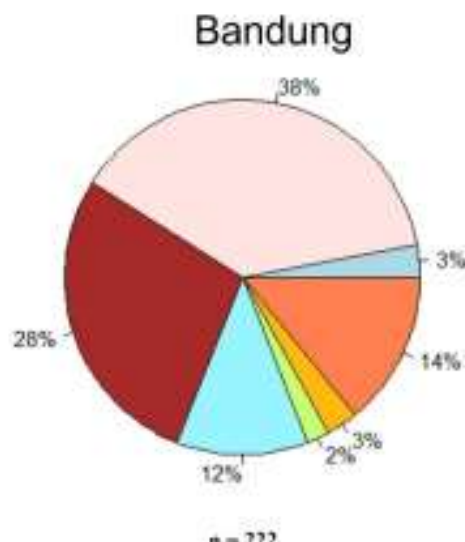

Entrepeneur/Merchant $\square$ student

(a)

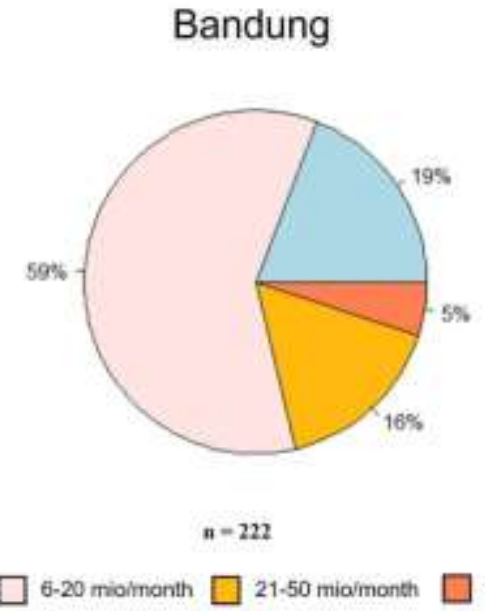

(b)

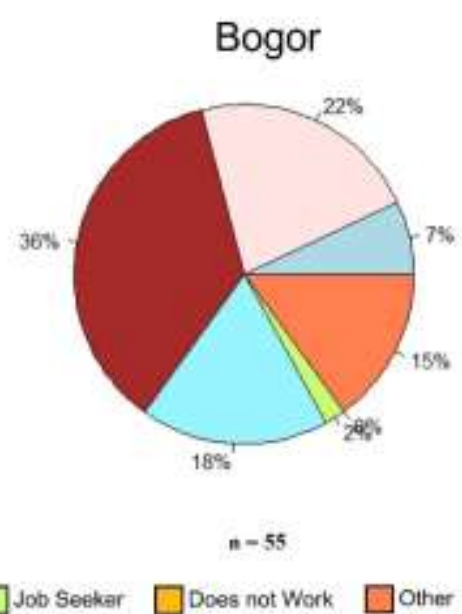

Bogor

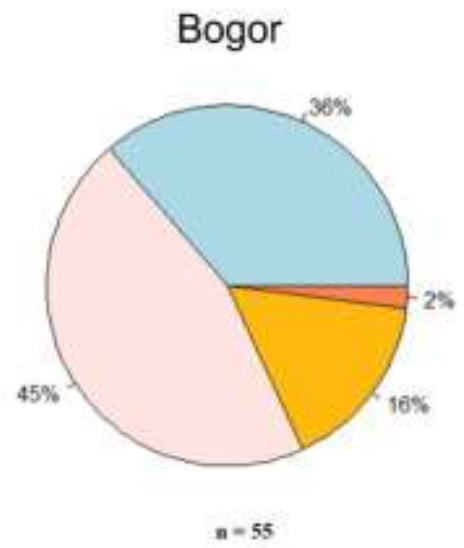

$n=55$

$>51$ mioimonth

istics

Figure 1 Respondent (a) Occupation; and (b) Income Characteristics

People in Bogor tend to be more skeptical, as only $65 \%$ of the respondents are willing to shift, noting that the base assumption during the interview states that the implementation of EURO IV would be mandatory.

However, the current socio-demographic data are not entirely accurate due to the imbalance and small number of respondents. As stated in the previous section, the current research is focused on the initial phase of public perception toward biofuel policy; hence, the data collection process is not massive. The variable distribution in Bogor, which has the smallest number of respondents, would seem to differ in comparison to the other cities, particularly if all cities are supposed to develop a similar distribution.

\subsection{Willingness to Pay}

The next process of the data analysis was to develop a willingness-to-pay diagram based on the collected data. In general, willingness to pay is the value that respondents are willing to spend considering the trade-off between two alternatives. The first step is to initialize a statistical analysis to determine the significant variables.

Table 3 shows the significant parameters used in the models. For the diesel model, the significant variables are fuel type, location, occupation, income, environmental awareness (based on EURO IV standard preference), and fuel price, whereas the significant variables for the non-diesel model are income, environmental awareness, and fuel price. 
Table 3 Statistical analysis of the model

\begin{tabular}{|c|c|c|c|c|c|c|c|c|c|c|}
\hline & \multicolumn{5}{|c|}{ Diesel } & \multicolumn{5}{|c|}{ Non-diesel } \\
\hline & est. & std.er & t-value & $\operatorname{Pr}(>t)$ & & est. & std. er & $\mathrm{t}$-value & $\operatorname{Pr}(>t)$ & \\
\hline ASC & -4.430 & 0.538 & -8.230 & $<2 \mathrm{e}-16$ & *** & 0.170 & 0.413 & 0.411 & 0.680 & \\
\hline Fuel Type (X $\left.\mathrm{X}_{1}\right)$ & 2.089 & 0.237 & 8.799 & $<2 \mathrm{e}-16$ & $* * *$ & & & & & \\
\hline Location $\left(\mathrm{X}_{2}\right)$ & 0.445 & 0.127 & 3.498 & 0.000 & $* * *$ & -0.087 & 0.137 & -0.633 & 0.526 & \\
\hline Occupation $\left(\mathrm{X}_{3}\right)$ & 0.221 & 0.058 & 3.769 & 0.000 & $* * *$ & 0.120 & 0.064 & 1.871 & 0.061 & \\
\hline Income $\left(\mathrm{X}_{4}\right)$ & 1.052 & 0.150 & 7.015 & $1.2 \mathrm{e}-12$ & $* * *$ & 0.781 & 0.132 & 5.900 & $3.63 e-9$ & $* * *$ \\
\hline Env. Aware $\left(\mathrm{X}_{5}\right)$ & 1.412 & 0.204 & 6.899 & $5.23 e-12$ & $* * *$ & 0.976 & 0.228 & 4.281 & $1.86 \mathrm{e}-5$ & $* * *$ \\
\hline Fuel Price $\left(\mathrm{X}_{6}\right)$ & -9.135 & 0.701 & -13.025 & $<2 \mathrm{e}-16$ & $* * *$ & -9.042 & 0.767 & -11.783 & $<22-16$ & $* * *$ \\
\hline log-likelihood & \multicolumn{5}{|c|}{-461.5958} & \multicolumn{5}{|c|}{-424.1463} \\
\hline
\end{tabular}

Table 4 Utility function for each type of vehicle

\begin{tabular}{lc}
\hline Vehicles & Utility Function \\
\hline Diesel & $-4.430+2.089 . \mathrm{X}_{1}+0.445 . \mathrm{X}_{2}+0.221 . \mathrm{X}_{3}+1.052 . \mathrm{X}_{4}+1.412 . \mathrm{X}_{5}-9.135 . \mathrm{X}_{6}$ \\
Non-diesel & $0.170-0.087 . \mathrm{X}_{2}+0.120 . \mathrm{X}_{3}+0.781 . \mathrm{X}_{4}+0.976 . \mathrm{X}_{5}-9.042 . \mathrm{X}_{6}$ \\
\hline
\end{tabular}

Based on the utility functions shown in Table 4, each sign indicates the people's willingness to shift into the new alternatives. For example, $\mathrm{X}_{2}$, which represents the study location, has an opposite value. The estimated value shows a positive sign for the diesel user but a sign for the non-diesel user. As stated in the previous chapter, the study locations are Jakarta, Bandung, and Bogor and are coded 1, 2, and 3, respectively. The positive estimation suggests that respondents in Bogor would have a higher probability of using biofuel, as the utility function would increase simultaneously. A negative estimation implies the opposite results, so respondents in Bogor would show a decrease in the utility function and a shifting probability. However, $\mathrm{X}_{2}$ is a nominal variable, and the use of ordinal variables would give a better understanding of the estimation value. $\mathrm{X}_{4}$ represents the respondents' income, and yet both models generate a positive value in the utility function. These results show that a rise in the respondents' income would also increase the probability of shifting, based on the higher utility function value.
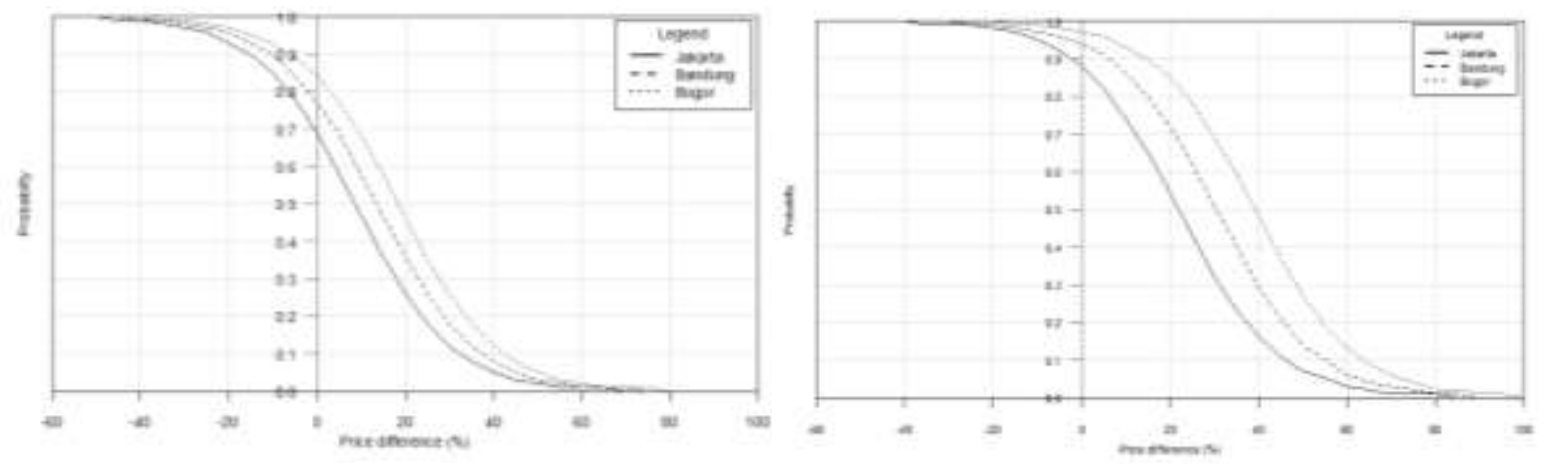

Figure 2 Willingness to pay for biofuel by: (a) Diesel users; and (b) Non-diesel users

Figure 2 shows the willingness-to-pay distribution function for diesel and non-diesel users. Here, the assumption is that the optimal price would fall when $50 \%$ of the people are willing to pay. People in Jakarta are willing to pay $5 \%$ higher than the current price, while people in Bandung and Bogor are willing to pay $10 \%$ and $15 \%$ higher. Interestingly, although people in Jakarta have the highest average income compared to the rest of the area, they are only willing to pay $5 \%$ more, or only one-third the amount that people in Bogor are willing to pay. The figure also demonstrates the willingness to pay among non- 
diesel users for using biofuel based on respondent region. The results show a similar pattern as seen for the diesel user probability function, where people in Bogor have the highest willingness to pay, followed by people in Bandung and then Jakarta, with 35\%, 30\%, and $20 \%$ willing to pay higher prices, respectively.

Generally, one of the significant differences between the two graphs is the gap between the regions. The closeness of the probability function for diesel users and non-diesel users generates a greater gap between the regions. One of the reasons for this phenomenon is the number of respondents. A larger number of respondents should generate more accurate results; thus, the close gap between each region shows the possibility that the probability function would be the same, given that the characteristics of each region are not significantly different. The non-diesel user probability function has a greater gap between regions due to the small number of samples. The inability to grasp a more accurate model of the sample resulted in a variability in people's willingness to pay.

\subsection{Potential Vehicle Growth}

According to the Association of Indonesia Automotive Industries (GAIKINDO) data regarding vehicle production, a cyclical pattern has been evident in vehicle production for the last 20 years. Therefore, the production trend can be forecast for the next 30 years (until 2050 ) based on the current data. Using the scenario and probability function from Figure 2, the previous trend can be transformed into a new potential growth trend based on the corresponding probability.

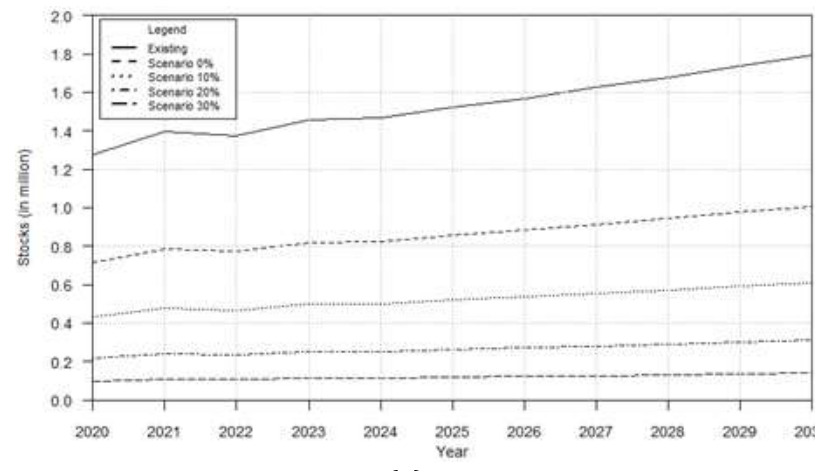

(a)

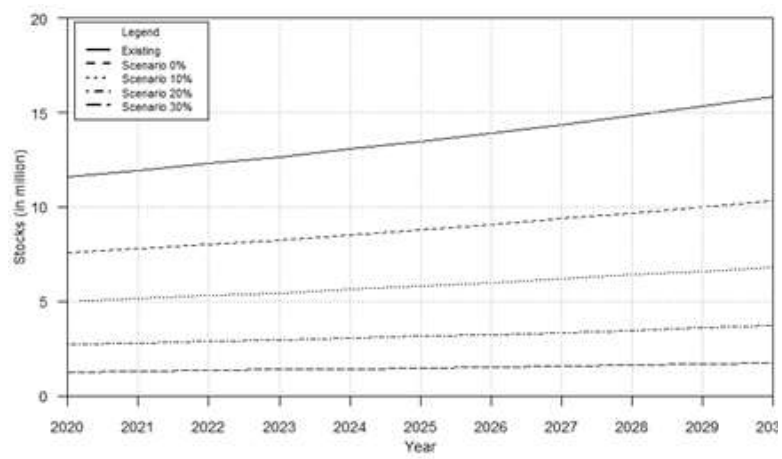

(b)

Figure 3 (a) Diesel vehicle potential growth; and (b) Gasoline vehicle potential growth

Figure 3 demonstrates the potential for vehicle growth for both diesel and gasoline vehicles. Fundamentally, the increasing price directly impacts the potential vehicle demand. If the biofuel price remains the same as the current fuel, in the next 10 years, gasoline vehicles will increase from approximately 12 million vehicles to around 16 million vehicles. In other words, the number of vehicles will increase by approximately 4 million in 10 years. This phenomenon presents a significant challenge for vehicle manufacturers and the automobile industry to keep pace with the potential demand in the next couple of years. Similarly, diesel vehicles would also experience significant increases depending on the price of the new fuel. Both forecasts show the relationship between price and the potential demand, as a higher hypothetical price will generate a flatter increase, as in the $30 \%$ scenario, where the line is relatively straight between 2020 and 2030, as the increase in demand is very small.

\section{Conclusions}

The Indonesian government intends to implement a biofuel program to increase palm oil production efficiency and to establish a new environmentally friendly fuel alternative. 
Consequently, the government senses a need to upgrade the emission standard from EURO II to EURO IV and to eliminate policy incentives, such as fuel subsidization, to complement the previous policy and achieve fuel sustainability. Based on our data collection, the majority of the respondents appear willing to pay for more expensive fuel if the policy is mandatory. Interestingly, Jakarta, as an urban area, showed the lowest willingness to pay compared to the other cities due to more varying respondent characteristics. The implementation of biofuel and the EURO IV policy will affect vehicle demand and purchases. Therefore, vehicle manufacturers need to be prepared for the increasing demand for particular types of vehicles.

\section{Acknowledgements}

The authors thank Dr. Alloysius Joko Purwanto, Mrs. Dian Lutfiana and Dr. Nuzul Achjar for the research collaboration initiative and discussion during the research.

\section{References}

Arnab, R., 2017. Survey Sampling Theory and Applications. Elsevier: Amsterdam, The Netherlands

Ben-Akiva, M., Lerman, S., 1985. Discrete Choice Analysis: Theory and Application to Travel Demand. 1st ed. MIT Press: Cambridge, MA, USA

Cavalcanti, M., Szklo, A., Machado, G., 2012. Do Ethanol Prices in Brazil Follow Brent Price and International Gasoline Price Parity? Renewable Energy, Volume 43, pp. 423-433

Demirbas, A., 2009. Progress and Recent Trends in Biodiesel Fuels. Energy Conversion and Management, Volume 50(1), pp. 14-34

Diamond, P., Hausman, J., 1994. Contingent Valuation: Is Some Number Better than No Number? Journal of Economic Perspectives, Volume 8(4), pp. 45-64

Fadiran, G., Sharma, T., Rogan, F., O'Gallachoir, B., 2021. Exploring a Case Transition to Low Carbon Fuel: Scenarios for Natural Gas Vehicles in Irish Road Freight. Available Online at https://papers.ssrn.com/sol3/papers.cfm?abstract_id=3855537

Grafton, R.Q., Kompas, T., Long, N.V., 2012. Substitution between Biofuels and Fossil Fuels: Is There a Green Paradox? Journal of Environmental Economics and Management, Volume 64(3), pp. 328-341

Hassan, M.H., Kalam, M.A., 2013. An Overview of Biofuel as a Renewable Energy Source: Development and Challenges. Procedia Engineering, Volume 56, pp. 39-53

Honore, B.E., Kyriazidou, E., 2000. Panel Data Discrete Choice Models with Lagged Dependent Variables. Econometrica, Volume 68(4), pp. 839-874

International Energy Agency, 2017. Energy Technology Perspective 2017, Paris: OECD

Jensen, F., Asmarini, W., 2016. Net Oil Importer Indonesia Leaves Producer Club OPEC, again. Reuters. Available Online at https://www.reuters.com/article/us-opec-meetingindonesia-idUSKBN13Q3M7. Accessed on March 15, 2021

Jensen, K., Clark, C.D., English, B.C., Menard, R.J., Skahan, D.K., Marra, A.C., 2010. Willingness to Pay for E85 From Corn, Switchgrass, and Wood Residues. Energy Economics, Volume 32(6), pp. 1253-1262

Kaniapan, S., Hassan, S., Ya, H., Nesan, K., Azeem, M., 2021. The Utilisation of Palm Oil and Oil Palm Residues and the Related Challenges as a Sustainable Alternative in Biofuel, Bioenergy, and Transportation Sector: A Review. Sustainability, Volume 13(6), p. 1-25

Karytsas, S., Theodoropoulou, H., 2014. Socioeconomic and Demographic Factors that Influence Publics' Awareness on the Different Forms of Renewable Energy Sources. Renewable Energy, Volume 71, pp. 480-485 
Kutas, G., Lindberg, C., Steenblik, R., 2007. Biofuels - At What Cost? Government Support for Ethanol and Biodiesel in the European Union, Geneva, Switzerland: International Institute for Sustainable Development. Available Online at: https://www.iisd.org/gsi/sites/default/files/oecdbiofuels.pdf

Li, T., McCluskey, J., 2017. Consumer Preferences for Second-Generation Bioethanol. Energy Economics, Volume 61, pp. 1-7

Ministry of National Development Planning, 2020. Rencana Pembangunan Jangka Menengah Nasional 2020-2024 (National Mid-Term Development Plan 2020-2024) Available Online at https://www.bappenas.go.id/id/berita-dan-siaran-pers/rencanapembangunan-jangka-menengah-nasional-rpjmn-2020-2024

Neonufa, G., Soerawidjaja, T., Prakoso, T., 2017. Catalytic and Thermal Decarboxylation of Mg-Zn Basic Soap to Produce Drop-in Duel in Diesel Boiling Ranges. Journal of Engineering and Technological Sciences, Volume 49(5), pp. 575-586

Ninni, A., 2010. Policies to Support Biofuels in Europe: The Changing Landscape of Instrument. AgBioForum, Volume 13(2), pp. 131-141

Organization of the Petroleum Exporting Countries, 2021. OPEC Statute, Vienna: OPEC Secretariat. Available Online at https://www.opec.org/opec_web/en/publications/345.htm

Ortuzar, J.d.D., Willumsen, L., 2011. Modelling Transport. $4^{\text {th }}$ ed. West Sussex: Wiley

Othman, M.F., Adam, A., Najafi, G., Mamat, R., 2017. Green Fuel as Alternative Fuel for Diesel Engine: A Review. Renewable and Sustainable Energy Reviews, Volume 80, pp. 694-709

Susaeta, A., Alavalapati, J., Lal, P., Matta, J.R., Mercer, E., 2010. Assessing Public Preferences for Forest Biomass Based Energy in the Southern United States. Environmental Management, Volume 45(4), pp. 697-710

Train, K., 2009. Discrete Choice Methods with Simulation. $2^{\text {nd }}$ edition Cambridge: Cambridge University Press

Tsay, Y., 2009. The Impacts of Economic Crisis on Green Consumption in Taiwan. In: Portland International Conference on Management of Engineering \& Technology, pp. 2367-2374

United Nations, 2016. Paris Agreement. Available Online at https://unfccc.int/files/essential_background/convention/application/pdf/english_p aris_agreement.pdf

Zailani, S., Iranmanesh, M., Hyun, S.S., Ali, M.H., 2019. Applying the Theory of Consumption Values to Explain Drivers' Willingness to Pay for Biofuels. Sustainability, Volume 11(3), pp. 1-13 